\title{
Examining the Relationships between Epistemological Beliefs and Teaching and Learning Conceptions of Lower-Secondary Education Teachers
}

\author{
Necla EKINCi \\ Muğla Sıtkı Koçman Üniversitesi
}

\begin{abstract}
The purpose of this study is to determine the relationships between lower-secondary education teachers' epistemological beliefs and their conceptions about teaching and learning. The sample of this descriptive study is comprised of 184 lower-secondary school teachers. As data collection tools, the Epistemological Belief Questionnaire $(E B Q)$ and the Teaching and Learning Conception Scale were used. In the analysis of the data, descriptive statistics, t-test, one-way variance analysis (ANOVA) and multiple regression analysis were employed. The findings of the study revealed that the teachers' level of beliefs about the sub-dimensions of Authority/Expert Knowledge and Learning Effort/Process was found to be high, their level of beliefs about the subdimension named as Innate/Fixed Ability was found to be medium and their level of beliefs about the sub-dimension of Certainty of Knowledge is low. Though the teachers mostly prefer constructivist conception to shape their instructional practices, they also have a considerable orientation towards the adoption of traditional conception. Moreover, it was concluded that the teachers' epistemological beliefs are a significant predictor of their preferences for constructivist and traditional teaching and learning conceptions.
\end{abstract}

Keywords: Epistemological beliefs, teaching and learning conceptions, constructivist conception, traditional conception, teacher education

\section{İnönü University}

Journal of the Faculty of Education

Vol 18, No 1, 2017

pp. 344-358

DOI: 10.17679/inuefd.307065

Received : 15.12.2016

Revision1 : 07.04.2017

Accepted : 15.04.2017

\section{Suggested Citation}

Ekinci, N. (2017). Examining the Relationships between Epistemological Beliefs and Teaching and Learning Conceptions of Lower-Secondary Education Teachers, Inonu University Journal of the Faculty of Education, 18(1), 344-358. DOI: 10.17679/inuefd. 307065 


\section{INTRODUCTION}

In recent years, the number of studies focusing on the subjects related to knowledge and learning has been increasing due to the importance attached to the interrelation between the fields of philosophy and education and in this regard, epistemology has become one of the prominent concepts (Demir \& Akınoğlu, 2010; Kaleci \& Yazıcı, 2012).

Epistemology is defined as a discipline investigating, researching and inquiring the nature, source, borders, accuracy, reliability and validity of knowledge and ways of acquiring and transferring it (Demir \& Acar, 1992). With this content, epistemology contributes to the construction of viewpoints concerning the definition, formation and learning of knowledge and at the same time, enables the evaluation of the viewpoints possessed by individuals. As a result of the experiences and interactions individuals undergo, they reach some permanent conceptions and beliefs about knowledge and its acquisition. These conceptions and beliefs make up an individual's epistemological beliefs. Schommer (1990) argues that epistemological beliefs have a scope going beyond the beliefs related to knowledge because they also cover the beliefs concerning learning and learning aptitude related to the processes of acquisition and use of knowledge and all of these should be regarded as a belief system. Individuals' belief levels regarding the dimensions of epistemological beliefs might be different from each other. For instance, while an individual thinks that knowledge has a simple and fixed structure, he/she might believe, on the other hand, that knowledge has a quite complex structure encompassing different ideas (Schommer \& Walker, 1997).

Schommer (1990) hypothesized epistemological dimensions as follows;

1. Source of knowledge: From knowledge is handed down by omniscient authority to knowledge is reasoned out through objective and subjective means. (Omniscient Authority)

2. Certainty of knowledge: From knowledge is absolute to knowledge is constantly evolving. (Certain Knowledge)

3. Organization of knowledge: From knowledge is compartmentalized to knowledge is highly integrated and interwoven. (Simple Knowledge)

4. Control of learning: From ability to learn is genetically predetermined to ability to learn is acquired through experience. (Fixed Ability)

5. Speed of learning: From learning is quick or not-at-all to learning is a gradual process. (Quick Learning)

Each person has either conscious or unconscious epistemological conception constructed on the basis of above mentioned hypotheses. This conception leads an individual to the development of a world view, permanent beliefs about knowledge and knowledge acquisition process. This is also true for all teachers and students. In the literature, there are some studies revealing that there is a relationship between the qualities of epistemological beliefs and instructional behaviors. It has been reported that there is a relationship between the epistemological beliefs possessed by students and learning products (Kızılgüneş, Tekkaya \& Sungur, 2009); that the thinking abilities of the students thinking relatively in relation to knowledge and learning are more sophisticated and thus they have better problem solving skills (Aksan $\&$ Sözer, 2007); that the students strongly believing that knowledge has a simple structure experience difficulties in understanding concepts taught in the course of Introduction to Statistics (Schommer, Crouse, \& Rhodes, 1992); that the students having sophisticated beliefs about the nature of knowledge and learning are more persistent in grasping a deep understanding of the content and in coping with challenging academic tasks (Schommer-Aikins \& Hutter, 2002). In a study by Kardash and Howell (2000), conducted on university students, it was found that the students strongly believing that learning will occur over time depending on the effort invested make use of more cognitive strategies while studying instructional materials; however, the students believing that learning will occur immediately or not intending to comprehend what they are reading are unsuccessful in understanding the text. Moreover, it has been revealed that epistemological beliefs possessed by students are positively correlated with higher level thinking (Schommer-Aikins \& Hutter, 2002), directly or indirectly with academic achievement (Schommer,1993; Schommer et al., 1992), locus of control (Deryakulu, 2002), study strategies (Deryakulu, 2014) preferred learning approaches (Chan \& Elliot, 2000; Chan, 2003; Cano, 2005; Özkal, Tekkaya, Çakıroğlu \& Sungur, 2009; Taşkın, 2012), intrinsic motivation, self-efficacy, self-regulation (Hofer, 2001), critical thinking and meta-cognition (Başbay, 2013), attitudes towards school (Schommer \& Walker, 1997). 
As it has been understood that epistemological beliefs possessed by individuals and development level have such a powerful influence on learning, it seems to be important to focus on factors that are influential on training individuals having sophisticated epistemological beliefs. Deryakulu (2014) identified the factors affecting the formation and development of epistemological beliefs as mental development, age, family structure, education and culture. Similarly, Demir and Akınoğlu (2010) point out that epistemological attitudes can be developed and the factors affecting this development are individual efforts and awareness, family effect and interest and the elements of formal and informal education and points to the importance of the teacher in the training of individuals who can correctly understand and interpret events, have critical inquiry skills and positive scientific attitudes. Though an external intervention with all the variables mentioned here is not possible, it seems to be possible to intervene in some of the variables regarding teaching and learning process. During the educational process, individuals must be enabled to the construct the required knowledge base and also they should be taught why scientific knowledge is important, how to differentiate it from the non-scientific, what are the sources and how to address its limits (Şengül-Turgut, 2007).

In this regard, teaching and learning conceptions adopted by teachers seem to be of great importance. Chan and Elliott (2004) contend that teaching and learning approaches preferred by teachers indicate their beliefs about the ways of teaching and learning and these beliefs encompass the meaning assigned to teaching and learning and teacher-student roles. The reason for the importance attached to epistemological beliefs in education is viewing our beliefs as factors directing our behaviors (Karhan, 2007). Teachers' belief and value systems affect their classroom strategies and performance by shaping their inclass instructional practices and concepts (Cheng, Chan, Tang \& Cheng, 2009; Hashweh, 1996; Kagan, 1992; Pajares, 1992). Gray (1997) argues that there is a shift in teachers' teaching and learning conceptions from traditional teaching and learning conception based on the transfer of knowledge in the design and application of education towards constructivist conception emphasizing the transformation of knowledge. These two conceptions of teaching and learning differ from each other in terms of their perceptions of the source of knowledge, the nature of learning and teacher-student roles. Constructivist learning strategies require the active participation of students in the process of making sense of or constructing the knowledge (Brovnlee, Thorpe \& Stacey, 2005). Şengül-Turgut (2007) points out that in fact the unity of both psychological and sociological theories having decisive roles in the organization of instructional environments has a background made up of epistemological acceptances and when the basis of both the constructivist and behaviorist approaches is examined, it is seen that the elements making them different are centered around the issue of knowledge. The constructivist epistemology emphasizes not the passive acquisition of knowledge but active construction of it by the learner. Cognition, in this process, is an adaptation process serving the function of making the individual's behaviors more complaint within a certain context and it organizes the individual's experiences and constructs the meaning (Tezci \& Uysal, 2004). İçen (2012) argues that the effect of the instructional environment constructed by teachers through their epistemological and scientific beliefs on the achievement is quite important and remarks that besides the nature of knowledge perceived by the student, the way of the presentation of knowledge to the student can affect the formation of quality learning environments. In this regard, the position of the student in the class, his/her way of using resources and his/her role in the class are important elements. Thus, the way of presenting epistemological evaluations conducted on the nature of knowledge, what knowledge is and its limits, sources and validity is of great importance. Deryakulu (2014) emphasizes the importance of establishing student-centered learning environments where students are provided with opportunities to construct knowledge, there are learning materials exposing students to multiple viewpoints and evaluation methods focusing on the evaluation of higher thinking skills and effort rather than rote learning is emphasized, so that teachers can support their students to have sophisticated epistemological beliefs. Thus, such research seems to consolidate the partnership between a sophisticated epistemological belief and constructivist approach. There is some research demonstrating that learningteaching environments constructed on the basis of constructivist approach help the individual to develop sophisticated epistemological beliefs. The research (Aypay, 2011a; Bacanlı-Kurt, 2010; Benson 1989; Cheng at al., 2009; Deryakulu, 2014; Gallagher, 1991; Hashweh, 1996; İçen, 2012; Kagan, 1992; Karhan, 2007; Pajares, 1992) revealed that epistemological beliefs are influential on variables such as the perception of the learner, methods and techniques adopted in teaching and learning process and classroom management skills. Windschitl and Andre (1998) concluded that while students having sophisticated epistemological beliefs learn better in a learning environment designed according to constructivist approach, students having unsophisticated epistemological beliefs learn better in a learning environment organized according to traditional approach (Hofer, 2001). In the literature, studies conducted with high 
school teachers (Akyıldız, 2014), civic education teachers (Ekici \& Kaya, 2016), classroom teachers (Özbaş, 2013) and pre-service teachers (Aypay, 2011a; Chan, 2003) reported that while there is a positive correlation between sophisticated epistemological beliefs and classroom practices developed on the basis of constructivist approach, there is a negative correlation between sophisticated epistemological beliefs and classroom applications developed on the basis of traditional approach.

In general, constructivist approach puts emphasis on the construction of learning environments on the basis of constructivist theory. Such environments promote critical thinking, discovery and cooperation. In these environments, students can exhibit the behaviors of solving real-life problems, cooperating in group works, writing a paper or story, developing a model, conducting inquiries to find solutions to research problems. Moreover, developing software programs offer unique opportunities to develop students' critical thinking and discovery skills and research has demonstrated that these variables have some effect on achievement; yet, the quality of the epistemological belief possessed by the teacher is the main determinant (Howard, Mcgee, Schwartz \& Purcell, 2000). Thus, it can be argued that as the epistemological belief possessed by the teacher who is the main determining factor involved in the design of learning environments finds some reflections on his/her classroom practices, for students to develop sophisticated epistemological beliefs, the teachers should have sophisticated beliefs about the nature and the source of learning. Şengül-Turgut (2007) maintains that serious revision of epistemological acceptances and consideration of them in the planning of education and instructional process are necessary for the facilitation of learning. The current study intends to determine the reflection of the relationship between teaching and learning conceptions and epistemological beliefs on teachers. In this way, the current study is believed to elicit the extent to which constructivist teaching and learning conception laying the basis of curricula put into practice in 2005 is adopted by teachers, how much teachers have distanced themselves from traditional teaching and learning conception and the effect of teachers' epistemological beliefs on this process.

In this regard, the purpose of this study is to determine the relationship between the lower-secondary education teachers' teaching and learning conception preferences and their epistemological beliefs. To this end, answers to the following questions were sought:

1. What are the epistemological beliefs of the teachers?

2. To what extend do the teachers favor constructivist and traditional teaching and learning conceptions?

3. Do the teachers' epistemological beliefs and preferences for teaching and learning conceptions vary significantly depending on their job seniority?

4. To what extent do the teachers' epistemological beliefs predict their teaching and learning conceptions?

\section{METHODOLOGY}

This study was designed as a relational descriptive research aiming to determine the relations between the teachers' epistemological beliefs and their teaching and learning conceptions. The relational descriptive research model is used in studies targeting to determine the existence of mutual change in at least two or more variables (Karasar, 1986).

\section{Population and Sample}

The population of this study is comprised of 283 lower-secondary school teachers from different branches working in the Menteşe province of the city of Muğla in the spring term of 2015-2016 school year. The minimum number of teachers that can represent this population with $95 \%$ reliability level was calculated to be 165 . Considering the possibility that some of the data collection tools could be returned uncompleted and/or with missing data, more teachers were reached and data collection tools suitable for analyses were collected from 184 teachers. In the sample specification process, each school was considered to be a cluster and the teachers to be included in the sample group were randomly selected by means of disproportional cluster sampling procedure. Of the participant teachers, 115 (62.5\%) are females and 69 (37.5\%) are males and 72 (39.1\%) have been working as a teacher for 1-10 years, 81 (44.0\%) for 11-20 years and $31(16.8 \%)$ for 21 years or more. 


\section{Data Collection}

The data of the study were collected through the administration of the Teaching and Learning Conceptions Scale and the Epistemological Belief Scale to the sample in the spring term of 2015-2016 school year. The psychometric properties of the scales for both their original forms and adapted forms are explained briefly below.

Teaching and Learning Conceptions Questionnaire (TLCQ). The Teaching and Learning Conception Questionnaire developed by Chan and Elliott (2004) and adapted to Turkish by Aypay (2011a) consists of two sub-dimensions that are constructivist teaching and learning conception (12 items) and traditional teaching and learning conception (18 items) and a total of 30 items. The scale items are designed in the form of five-point Likert scale (ranging from $1=$ Strongly disagree to $5=$ Strongly agree). The higher the score for a dimension is, the higher the dimension is favored. For a better understanding of the conceptions, two items are given below for each conception from the original form of the questionnaire (Chan \& Elliott, 2004).

\begin{tabular}{ll}
\hline Dimensions & Items \\
\hline Constructivist Conception & Good teachers always encourage students to think for answers themselves \\
& Learning means students have ample opportunities to explore, discuss and \\
& express their ideas. \\
& Every child is unique or special and deserves an is important that a teacher \\
& understands the feelings of the students \\
& Good teachers always encourage students to think for answers themselves. \\
& During the lesson, it is important to keep students confined to the \\
traditional Conception & Learning means remembering what the teacher has taught. \\
& Good students keep quiet and follow teacher's instruction in class. \\
& Good teaching occurs when there is mostly teacher talk in the classroom. \\
\hline
\end{tabular}

The Turkish version of the scale obtained from the adaptation study was administered to 341 pre-service teachers and confirmatory factor analysis (CFA) was applied to the collected data to determine the construct validity of the scale. The goodness-of-fit indices of the model obtained from CFA were examined and Chi-square value was found to be significant $\left(x^{2}=1020,3, N=341, s d=404, p=0.00\right)$. The other goodness-of-fit indices obtained with CFA are as follows: RMSEA $=0.067, \mathrm{NFI}=0.72, \mathrm{CFI}=0.80$. In order to determine the reliability of the scale, Cronbach's alphas for the original form of the scale were found to be 0.84 for the whole scale; 0.88 for the constructivist teaching and learning conception and 0.83 for the traditional teaching and learning conception (Aypay, 2011a). Cronbach's alphas were recalculated on the data of the current study and it was found to be 0.80 for the whole scale, 0.84 for the sub-dimension of constructivist teaching and learning conception and 0.89 for the sub-dimension of traditional teaching and learning conception.

Epistemological Belief Questionnaire (EBQ) was developed by Chan and Elliot $(2002,2004)$ on the basis of 63-item Epistemological Belief Questionnaire of Schommer (1990) and was adapted to Turkish by Aypay (2011b). The scale is comprised of four sub-dimensions that are Authority/Expert Knowledge (11 items), Innate/Fixed Ability (8 items), Learning Effort/Process (5 items), Certainty of Knowledge (6 items) and thus a total of 30 items. The scale items are organized in the form of five-point Likert-type scale (ranging from $5=$ Strongly agree to $1=$ Strongly disagree). For a better understanding of $E B Q$, again two items are given below for each dimension from the original form of the questionnaire (Chan \& Elliott, 2004).

\begin{tabular}{ll}
\hline Dimensions & Items \\
\hline Authority/Expert Knowledge & $\begin{array}{l}\text { Sometimes, I don't believe the facts in textbooks written by authorities } \\
\text { Innate/Fixed Ability }\end{array}$ \\
& $\begin{array}{l}\text { Even advice from experts should often be questioned. } \\
\text { fixed at birth } \\
\text { One's innate ability limits what one can learn. } \\
\text { If people can't understand something right away, they should keep on } \\
\text { trying. } \\
\text { Knowing how to learn is more important than the acquired facts. } \\
\text { Sertainty Knowledge }\end{array} \quad \begin{array}{l}\text { Scientists will ultimately get to the truth if they keep searching for it. } \\
\text { Scientific knowledge is certain and does not change. }\end{array}$ \\
\hline
\end{tabular}


The Turkish form of the scale constructed for the adaptation study of the scale was administered to the above-mentioned group of pre-service teachers and by applying exploratory factor analysis and confirmatory factor analysis to the collected data, the construct validity of the scale was tested. As a result of exploratory factor analysis (EFA), the above-mentioned four factors emerged and the total variance explained by these dimensions was calculated to be $37.18 \%$. The factor loadings of the items encompassed by the first factor were found to be ranging from 0.73 to 0.36 ; those of the items in the second factor were found to be ranging from 0.73 and 0.37 ; those of the items included in the third factor were found to be ranging from 0.63 to 0.49 and those of the items covered by the fourth factor were found to be ranging from 0.56 to 0.39 . Within the study group of the current study, the goodness-of-fit index of the model related to the Epistemological Belief Scale was tested with confirmatory factor analysis (CFA). Chi-square value calculated in relation to the model data compliance is significant $\left[\chi^{2}=795.7, d f=399, p=.00\right]$. Chisquare degree of freedom ratio including the effect of sampling size was found to be quite low $(795.7 / 399=1.99)$. The other goodness-of-fit indices of the scale are as follows: RMSEA $=0.05, C F I=0.77$, $\mathrm{IFI}=0.78$ and NFI 0.64. As a result, the analyses yielded a model in compliance with the factor structure of the adapted scale. The reliability of the scale was tested with Cronbach's alphas. Thus, they were .77 for Authority/Expert Knowledge, .74 for Innate/Fixed Ability, .59 for Learning Effort/Process and .52 for Certainty of Knowledge (Aypay, 2011b).

The reliability of the scale was tested through Cronbach's Alphas calculated on the data of the current study. Thus, they were .74 for Authority/Expert Knowledge, .77 for Innate/Fixed Ability, .64 for Learning Effort/Process and .64 for Certainty of Knowledge.

\section{Data Analysis}

In the analysis of the data, descriptive statistics were used; while comparing means in terms of some variables, $t$-test $(t)$ was employed when there were two variables and one-way variance analysis (ANOVA) was conducted when there were three or more variables. For the significant Fs, LSD test was used to determine the source of the difference. In order to determine the effect size of the difference for ts and Fs, $\eta^{2}$ (eta-squared) statistics was used. $\eta^{2}$ shows the variance explained by independent variables in dependent variable. If $\cdot \eta^{2}$ value is between .01 and .05 , it indicates a lower effect size, if it is between .06 and .13, it indicates a moderate effect size and if it is higher than .14, it indicates a high effect size (Büyüköztürk, 2014). Multiple-regression analysis was conducted to determine to what extent epistemological beliefs of teacher predict their teaching and learning conceptions. Prior to the regression analysis, suitability of the data was checked. In this connection, outlier value analysis was run; $z$ scores were calculated to determine the outlier values. As there was no data with a $z$ value \pm 3 or over $(z< \pm 3)$, no reduction was needed. The normality of the distribution was tested by calculating skewness and kurtosis coefficients. In all the variables, skewness coefficients were calculated to be ranging from -.040 to -.746 and kurtosis coefficients were calculated to be ranging from -.008 to - .515 . As these coefficients are in the range of \pm 1 , the distribution was accepted to be normal. Whether there was multicollinearity between the variables was determined with variance inflation factor (VIF) analysis and non-standardized regression coefficients (B). As in the current study, the highest VIF value was calculated to be 1.62 and the highest $B$ value was calculated to be .56 , it was accepted that there is no problem of multicollinearity. A VIF value higher than 10 (Myers, 1990) or a B value higher than 2 (Çokluk, 2010) indicates the existence of multicollinearity problem.

\section{FINDINGS}

In this section, findings obtained regarding the sub-problems of the study are presented.

As can be seen in Table 1, the secondary school teachers have a high level of beliefs of Authority/Expert Knowledge $(M=3.87, S D=.50)$, a low level of beliefs about learning's being restricted to Innate/Fixed Ability $(M=2.51, S D=.66)$, a high level of beliefs of Learning Effort/Process $(M=3.57, S D=.62)$ and a moderate level of beliefs about the Certainty of Knowledge $(M=2.65, S D=.66)$.

In Table 1, it is also seen that while the teachers prefer constructivist teaching and learning conception to a great extent $(M=4.36, S D=.48)$, they prefer traditional teaching and learning conception to a lower but considerable extent $(M=2.57, S D=.67)$. 
Table 1.

Descriptive results related to epistemological beliefs and teaching and learning conceptions $(n=184)$

\begin{tabular}{llll}
\hline & Sub-dimensions & $\boldsymbol{M}$ & SD \\
\hline \multirow{4}{*}{ Epistemological } & Authority/Expert Knowledge & 3.87 & .50 \\
beliefs & Innate/Fixed Ability & 2.51 & .66 \\
& Learning Effort/Process & 3.57 & .62 \\
\multirow{2}{*}{ Teaching and learning } & Certainty of Knowledge & 2.65 & .66 \\
\cline { 2 - 4 } conceptions & Constructivist & 4.36 & .48 \\
& Traditional & 2.57 & .67 \\
\hline
\end{tabular}

The teachers' mean scores for the sub-dimensions of their epistemological beliefs do not vary significantly depending on the job seniority [Authority/Expert Knowledge: $F_{(2-181)}=2.108 ; \mathrm{p}>.05$; Innate/Fixed Ability: $F_{(2-}$ $181)=.978 ; p>.05$; Learning Effort/Process: $F_{(2-181)}=.593 ; p>.05$ and Certainty of Knowledge: $F_{(2-181)}=.173$; $\mathrm{p}>$.05].

Table 2.

Comparison of the descriptive results related to epistemological beliefs and teaching and learning conceptions of teachers by their seniority $(n=184)$

\begin{tabular}{|c|c|c|c|c|c|c|c|c|c|}
\hline 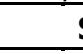 & Sub-dimensions & Seniority & $n$ & $M$ & $S$ & $d f$ & $F$ & Difference & $\eta^{2}$ \\
\hline \multirow{12}{*}{ 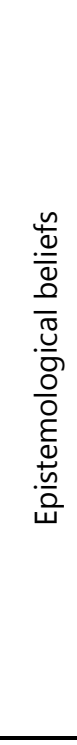 } & \multirow{3}{*}{$\begin{array}{l}\text { Authority/Expert } \\
\text { Knowledge }\end{array}$} & $1-10$ years & 72 & 3.95 & .45 & 2 & 2.108 & - & - \\
\hline & & $11-20$ years & 81 & 3.84 & .51 & 181 & & & \\
\hline & & $\begin{array}{l}\text { 21years or } \\
\text { more }\end{array}$ & 31 & 3.74 & .57 & 183 & & & \\
\hline & \multirow{3}{*}{ Innate/Fixed Ability } & $1-10$ years & 72 & 2.44 & .65 & 2 & .978 & - & - \\
\hline & & $11-20$ years & 81 & 2.53 & .65 & 181 & & & \\
\hline & & $\begin{array}{l}21 \text { years or } \\
\text { more }\end{array}$ & 31 & 2.63 & .69 & 183 & & & \\
\hline & \multirow{3}{*}{$\begin{array}{l}\text { Learning } \\
\text { Effort/Process }\end{array}$} & $1-10$ years & 72 & 3.60 & .66 & 2 & .593 & - & - \\
\hline & & $11-20$ years & 81 & 3.52 & .61 & 181 & & & \\
\hline & & $\begin{array}{l}21 \text { years or } \\
\text { more }\end{array}$ & 31 & 3.65 & .56 & 183 & & & \\
\hline & \multirow{3}{*}{$\begin{array}{l}\text { Certainty of } \\
\text { Knowledge }\end{array}$} & $1-10$ years & 72 & 2.62 & .64 & 2 & .173 & & \\
\hline & & $11-20$ years & 81 & 2.68 & .70 & 181 & & & \\
\hline & & $\begin{array}{l}21 \text { years or } \\
\text { more }\end{array}$ & 31 & 2.67 & .61 & 183 & & & \\
\hline \multirow{6}{*}{ 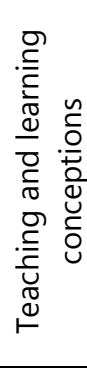 } & \multirow{3}{*}{ Constructivist } & $1-10$ years & 72 & 4.44 & .42 & 2 & 2.150 & - & - \\
\hline & & $11-20$ years & 81 & 4.35 & .495 & 181 & & & \\
\hline & & $\begin{array}{l}21 \text { years or } \\
\text { more }\end{array}$ & 31 & 4.23 & .58 & 183 & & & \\
\hline & \multirow{3}{*}{ Traditional } & $1-10$ years $(A)$ & 72 & 2.37 & .61 & 2 & $6.758^{*}$ & $A-B$ & .069 \\
\hline & & $11-20$ years $(B)$ & 81 & 2.64 & .63 & 181 & & $A-C$ & \\
\hline & & $\begin{array}{l}21 \text { years or } \\
\text { more }(C)\end{array}$ & 31 & 2.86 & .78 & 183 & & $B-C$ & \\
\hline
\end{tabular}

${ }^{*} p<0.05$,

As can be seen in Table 2, while the teachers' scores related to their preferences for constructivist teaching and learning conception do not significantly vary depending on their length of seniority $\left[F_{(2-181)}=2.150\right.$, $\mathrm{p}>.05]$, their scores related to their preferences for traditional teaching and learning conception vary significantly depending on their seniority length $\left[F_{(2-181)}=6.758, p<.05\right]$. The comparisons made among the three seniority groups revealed that the difference between these three groups is significant and with increasing length of service, means related to preference for traditional teaching and learning conception also increases. According to the calculated $\eta^{2}$ value (.069), the job seniority has a moderate impact on the preference for teaching and learning conception. 
Table 3.

Regression Analysis Results Related to What Extend Epistemological Beliefs of the Teachers Predict Their Constructivist Teaching and Learning Conception

\begin{tabular}{llllllll}
\hline Variable & $\boldsymbol{B}$ & $\begin{array}{l}\text { Standar } \\
\boldsymbol{d} \text { error }\end{array}$ & $\boldsymbol{\beta}$ & $\boldsymbol{t}$ & $\boldsymbol{p}$ & $\begin{array}{c}\text { Zero- } \\
\text { order(r) }\end{array}$ & $\begin{array}{c}\text { Partial } \\
(\boldsymbol{r})\end{array}$ \\
\hline Constant & 2.622 & .259 & & 10.118 & .00 & & \\
Authority/Expert Knowledge & .564 & .063 & .588 & 8.923 & .00 & .60 & .56 \\
Innate/Fixed Ability & -.122 & .053 & -.166 & -2.306 & .02 & -.26 & -.17 \\
Learning Effort/Process & -.011 & .054 & -.014 & -.199 & .84 & .17 & -.02 \\
Certainty of Knowledge & -.035 & .054 & -.048 & -.645 & .52 & -.17 & -.05 \\
\hline & $R=, 63$ & $R^{2=} .40$ & $F_{(4-179)}=29.888, p=.00$ & & \\
\hline
\end{tabular}

As can be seen in Table 3, the teachers' epistemological beliefs are an important predictor of their preferences for constructivist teaching and learning conception $(R=.63, R 2=.40, p<.01)$. The teachers' epistemological beliefs explain $40 \%$ of their preferences for constructivist conception. According to standardized regression coefficient $(\beta)$, the rank of importance of the predictor variables in terms of their impact on the teachers' preferences for constructivist teaching and learning conception is as follows; Authority/Expert Knowledge, Innate/Fixed Ability, Learning Effort/Process and Certainty of Knowledge. When the t-test results concerning the significance of regression coefficients were examined, it was found that of the sub-dimensions of epistemological beliefs, Authority/Expert Knowledge and Innate/Fixed Ability are significant predictors of constructivist conception; yet, Learning Effort/Process and Certainty of Knowledge do not have a significant influence on constructivist conception.

When zero order correlation coefficients were examined, it was found that the teachers' level of preference for constructivist teaching and learning conception has a positive and high correlation with the subdimension of Authority/Expert Knowledge $(r=.60)$, a negative and low correlation with the sub-dimension of Innate/Fixed Ability ( $r=-.26)$, a positive and low level correlation with the sub-dimension of Learning Effort/Process $(r=.17)$ and a negative and low correlation with the Certainty of Knowledge $(r=-.17)$. When the other variables were controlled, it was found that there is a positive and medium correlation between constructivist teaching and learning conception and the sub-dimension of Authority/Expert Knowledge ( $r=$ .56) and there is a negative and low correlation between constructivist teaching and learning conception and the sub-dimension of Innate/Fixed Ability $(r=-.17)$.

Table 4.

Regression Analysis Results Related to What Extent to Epistemological Beliefs of the Teachers Predict Traditional Teaching and Learning Conception

\begin{tabular}{llcccccc}
\hline Variable & $\boldsymbol{B}$ & $\begin{array}{c}\text { Standard } \\
\text { error }\end{array}$ & $\boldsymbol{\beta}$ & $\boldsymbol{t}$ & $\boldsymbol{p}$ & $\begin{array}{c}\text { Zero } \\
\text { order }(\boldsymbol{r})\end{array}$ & $\begin{array}{c}\text { Partial } \\
(\boldsymbol{r})\end{array}$ \\
\hline Constant & 1.448 & .372 & & 3.890 & .00 & & \\
Authority/Expert Knowledge & -.282 & .091 & -.211 & -3.102 & .00 & -.15 & -.23 \\
Innate/Fixed Ability & .198 & .076 & .195 & 2.616 & .01 & .46 & .19 \\
Learning Effort/Process & .222 & .077 & .205 & 2.871 & .00 & .27 & .21 \\
Certainty of Knowledge & .349 & .077 & .345 & 4.535 & .00 & .53 & .32 \\
\hline \multicolumn{2}{l}{} & \multicolumn{2}{c}{$R^{2}=.36$} & $F_{(4-179)}=25.277, p=.00$ & & & \\
\hline
\end{tabular}

As can be seen in Table 4, the teachers' epistemological beliefs are an important predictor of their preferences for traditional teaching and learning conception $(R=.60, R 2=.36, p<.01)$. The teachers' epistemological beliefs explain $36 \%$ of their preferences for traditional teaching and learning conception. According to standardized regression coefficient ( $\beta$ ), the rank of importance of the predictor variables in terms of their impact on the teachers' preferences for traditional teaching and learning conception is as follows; Certainty of Knowledge, Authority/Expert Knowledge, Learning Effort/Process and Innate/Fixed Ability. When the t-test results concerning the significance of regression coefficients were examined, it was seen that all of the sub-dimensions of epistemological beliefs; Certainty of Knowledge, Innate/Fixed Ability, Learning Effort/Process and Authority/Expert Knowledge, are significant predictors of the preference for traditional teaching and learning conception.

When the zero order correlation coefficients were examined, it was found that the teachers' level of preference for traditional teaching and learning conception has a negative and medium correlation with the sub-dimension of Authority/Expert Knowledge $(r=-.15)$, a positive and medium correlation with the 
sub-dimension of Innate/Fixed Ability $(r=.46)$, a positive and low correlation with the sub-dimension of Learning Effort/Process $(r=.27)$ and a positive and medium correlation with the certainty of knowledge $(r=.53)$. When the other variables were controlled, it was found that traditional teaching and learning conception has a negative and low correlation with the sub-dimension of learning process/being skeptical of knowledge $(r=-.23)$, a positive and low correlation with the sub-dimension of Innate/Fixed Ability ( $r=$ .19), a positive and low correlation with the sub-dimension of learning effort $(r=.21)$ and a positive and low correlation with the sub-dimension of Certainty of Knowledge $(r=.32)$.

\section{DISCUSSION CONCLUSION AND RECOMMENDATIONS}

When the results concerning the epistemological beliefs possessed by the teachers are examined, it can be seen that their levels of beliefs about the importance of learning process, the necessity of questioning the learning process and dependence of learning on the learner's effort are high. Their level of beliefs about the certainty and of knowledge is medium and their level of beliefs about learning ability is innate and fixed is low. Individuals believing that knowledge is not certain or absolute, that it can be correct or false depending on the situation, that it has a complex structure comprised of many interrelated pieces, that it is constructed by the individual by means of reasoning or on the basis of experimental evidence, that learning ability can be developed and learning depends on the learner's effort are considered to have sophisticated epistemological beliefs (Deryakulu, 2002). When the findings of the current study are evaluated within these criteria, it can be argued that the teachers do not have a holistic but a partial epistemological sophistication. For instance, while the teachers' belief that learning depends on effort is quite high, their belief about unchangeability of knowledge is not low enough. The relevant literature has reported that the teachers working in the lower-secondary education strongly believe that learning depends on effort and innate abilities and traits do not have a direct effect on learning (Özdemir \& Köksal, 2014), classroom teachers have a more sophisticated conception of science (Özbaş, 2013), civic teachers strongly believe that learning depends on effort (Ekici \& Kaya, 2016), epistemological beliefs of classroom teachers and branch teachers are closer to sophisticated scientific conception (Bacanlı-Kurt, 2010), though they are somehow under the influence of traditional approach, civic teachers are closer to sophisticated epistemological beliefs and open to innovations (Içen, 2012), high school teachers have sophisticated epistemological beliefs in terms of "the source of knowledge is the expert" and "learning is a matter of ability", they strongly believe that learning depends on effort and are closer to positivist objectivist beliefs in relation to the certainty of knowledge (Akyıldız, 2014). In the studies conducted on pre-service teachers, Kaleci (2012) found that while the participants have more sophisticated beliefs in terms of the dimension of dependence of learning on effort, they have less sophisticated beliefs about the other dimensions, Aypay (2011b) reported that the pre-service teachers demonstrate a great tendency to believing that knowledge acquisition process is important in learning, expert knowledge needs to be questioned and effort is important for learning; yet, they are not much prone to believe in the innate and fixed ability and certainty of knowledge. Köse and Dinç (2012) found that the pre-service teachers have the highest mean score for the dimension that learning depends more on ability rather than effort; on the other hand, Oğuz (2008) found that beliefs about the certainty of knowledge are stronger.

The current study and other research focusing on this subject show that while both teachers and preservice teachers have more sophisticated beliefs in terms of some dimensions, they have less sophisticated beliefs in other dimensions. Deryakulu (2014) argues that individuals' epistemological beliefs can be sophisticated or unsophisticated in a certain dimension independent of the other dimensions. In the current study, the teachers expressed more positive opinions about the dimensions of epistemological beliefs (indicators) and they expressed less positive opinions about the indicators of unsophisticated beliefs, which indicate that the teachers have more sophisticated beliefs about the source of knowledge and learning and its acquisition. This finding should be evaluated as positive in terms of the quality of learning environments. Teachers' beliefs and value systems shape their classroom practices and concepts and thus affect their classroom performance and teaching strategies (Bacanlı-Kurt, 2010; Benson 1989; Cheng at al., 2009; Gallagher, 1991; Hashweh, 1996; İçen, 2012; Kagan, 1992; Karhan, 2007; Pajares, 1992). While in an environment where individuals are viewed as passive knowledge storages the focus is on pure knowledge conveyance, in an environment where individuals are viewed as effective knowledge constructors the focus is mostly on the development of meaning and understanding (Şengül-Turgut, 2005). Teaching and learning environments designed on the basis of a sophisticated epistemological belief positively affect the learner's learning and lays the ground for them to consciously or unconsciously develop sophisticated beliefs. One of the variables affecting the epistemological belief possessed by the 
learner is the educational and instructional elements that can be formally or informally given and epistemology is a dynamic field that can both affect the field of education and can be affected by the educational process (Demir \& Akınoğlu, 2010). In fact, it has been revealed that the individuals' sophisticated epistemological beliefs are positively correlated with higher level thinking and being persistent in accomplishing challenging academic tasks (Schommer-Aikins \& Hutter, 2002), academic achievement (Schommer, 1993), problem solving skills (Aksan \& Sözer, 2007), intrinsic motivation, selfefficacy, self-regulation (Hofer, 2001), critical thinking and meta-cognition (Başbay, 2013), attitudes towards school (Schommer \& Walker, 1997), use of more cognitive strategies while learning (Kardash \& Howell, 2000), locus of control (Deryakulu, 2002), deep learning approach (Cano, 2005; Cano \& Rodriguez, 2006; Chan, 2003; Chan \& Elliot 2000; Taşkın, 2012) and intrinsic motivation (Karataş, 2011).

When the results of the current study related to teaching and learning conception are examined, it is seen that the teachers have a high level of preference for constructivist teaching and learning conception and a nearly medium level of preference for traditional teaching and learning conception. This finding is similar to the findings reported in the literature (Aydın, Tunca \& Alkın-Şahin 2015; Aypay 2011a; Baş, 2015; Ekinci, 2016; Engin \& Daşdemir, 2015; Işıkoğlu, Baştük \& Karaca, 2009; Oğuz, 2011). In this regard, it has been reported in the literature that high school teachers have adopted constructivist learning approach and are hesitant about traditional approach (Akyıldız, 2014) and civic teachers try to conduct instructional activities complying more with constructivist approach (İçen, 2012).

In the current study it was found that the teachers' preference for constructivism is high and this is a desired situation for the quality of teaching and learning environments. Demirel (2007) maintains that in classroom environments dominated by constructivist approach, great opportunities are provided for students, teachers enable their students to focus on big thoughts, take students' interests into consideration so that students can reformulate ideas, create connections and reach certain conclusions and share the belief that the world is a complicated place and fact is a matter of interpretation with their students. Constructivist learning approach gives priority to the development of critical thinking, inquiry, problem solving, entrepreneurship and decision-making skills (Kalaycl, 2014). In the literature (Akkaya, 2010; Çetin \& Günay, 2007; Kaya \& Tüfekçi, 2008; Önen, 2005; Özdoğan, 2008; Saygın, Atılboz \& Salman, 2006; Şengül-Turgut, 2007), it was reported that learning environments organized according to constructivist teaching and learning conception have positive effects on student learning outputs/. In this regard, the teachers' preferences for constructivist conception found in the current study can be positively evaluated in terms of learning environments. On the other hand, the teachers' medium or low level of preference for traditional teaching and learning conception found in the current study is supported by some other studies and this can be seen as a common conflict within the education system. This conflict stems from the use of considerable amount of traditional approach teaching practices although the present curricula which were put into effect in 2005 were developed on the basis of constructivist conception There can be various reasons behind this such as not being able to get rid of past habits, not adopting new roles, physical conditions, exam system etc. There are some studies showing that it is difficult to change teachers' beliefs in short terms (Richardson, 1996) and teachers usually teach as they have been taught by their former teachers (Woolley, Benjamin \& Woolley, 2004). The teachers' not completely abolishing traditional approach can be a preference or a sign of a deficit. Research findings showi that problems are experienced in the application of constructivist approach (Anagün, Yalçınoğlu \& Ersoy, 2012; Çiftçi, Sünbül \& Köksal, 2013; Yanpar-Yelken, Tanrıseven \& Kılıç, 2010) seems to be supporting this interpretation.

The teachers' epistemological beliefs do not vary significantly depending on the length of stheir seniority in this study. Teachers with different lengths of seniority have similar beliefs about the sub-dimensions of authority/expert knowledge, innate/fixed ability, learning effort/process, certainty of knowledge. But there exist some studies having contrary results. In a study by Akyıldız (2014), it was found that in some dimensions of epistemological beliefs, with increasing experience, their unsophisticated beliefs related to epistemology also increase. Karhan (2007) reported that the teachers having a professional experience of 1-10 years have more sophisticated beliefs than the teachers with a professional experience of 26 years or more. In their study, Özdemir and Köksal (2014) found that novice lower-secondary school teachers (0-5 years of experience) more strongly believe that learning is independent of ability, learning is not dependent on innate traits and knowledge can be acquired by everyone if the required effort is put forth; however, teachers with a professional experience of 26 years or more strongly believe that innate characteristics and abilities are influential on learning. 
The teachers' preference for constructivist conception does not vary significantly depending on their job seniority. On the other hand, their preference for traditional conception was found to be significantly varying depending on their seniority. In a study conducted by Ekinci (2016) with classroom teachers the tendency of more experienced teachers towards traditional approach is higher and though statistically not significant, the younger teachers' preference for constructivist conception is stronger. Akyıldız (2014) also reported that the high school teachers with a seniority of 1-5 years adopt constructivist conception to a greater extent and traditional conception to a lesser extent than the more experienced teachers. İçen (2012) concluded that the civic education teachers with a job seniority of 21 years or more make use of more student-centered instructional strategies and include them more in their classroom activities than the teachers with a seniority of 1-10 years. There are also some studies supporting the finding that more experienced teachers adopt constructivist approach to a greater extent and receive themselves to be more proficient (Akça, 2007; Işıkoğlu et al., 2009; Özenç \& Doğan, 2007). In a study by Engin and Daşdemir (2015), length of seniority was found to be not leading to a significant difference in the classroom teachers' teaching and learning conception. Gaining professional experience can be both advantage and disadvantage for teachers. Gaining professional experience by following the developments in the field and enhancing student-centered viewpoint can help teachers acquire more innovative conception of education. Otherwise, the preference of the teachers who are in the profession for years for traditional conception would be reinforced. In light of the findings of the current study, it can be maintained that design and application of constructivist curricula, recognizing and adapting to changing teacher-student roles could be easier for younger teachers.

When the results related to what extent epistemological beliefs predict the teachers' preferences for teaching and learning conceptions are examined, it is seen that the teachers' epistemological beliefs predict their preferences for teaching and learning conceptions to a great extent. This can be interpreted as the epistemological beliefs possessed by the teachers have a strong influence on their teaching and learning conceptions. This finding is supported in the literature (Aypay, 2011a; Bacanlı-Kurt, 2010; Benson 1989; Cheng at al., 2009; Deryakulu, 2014; Gallagher, 1991; Hashweh, 1996; İçen, 2012; Kagan, 1992; Karhan, 2007; Pajares, 1992) reporting that teachers' conceptions affect many aspects of their instruction ranging from their general viewpoints of education and the learner to the methods, techniques, classroom management skills they utilize. The research shows that teachers' epistemological beliefs are decisive in terms of which teaching approaches they adopt in general and the quality and quantity of teaching strategies they use during classroom practices in particular (Deryakulu, 2014).

When the other variable are controlled, the main variables affecting the teachers' preference for constructivist teaching and learning conception seem to be the sub-dimensions of authority/expert knowledge and Innate/Fixed Ability. It is seen that constructivist conception has a positive and medium correlation with the sub-dimension of authority/expert knowledge and a negative and low correlation with the sub-dimension of innate/fixed ability. The findings obtained related to main variables affecting the teachers' preference for traditional teaching and learning conception and the correlations between them are as follows: traditional teaching and learning perception has a negative and low correlation with the sub-dimension of authority/expert knowledge; a positive and low correlation with the sub-dimension of learning effort; a positive and low correlation with the sub-dimension of innate/fixed ability. That is, the teachers' sophisticated epistemological beliefs are in a positive correlation with constructivist teaching and learning conception and are in a negative correlation with traditional teaching and learning conception. Similar findings were reported by studies conducted with high school teachers (Akyıldız, 2014), civic education teachers (Ekici \& Kaya, 2016), classroom teachers (Özbaş, 2013) and pre-service teachers (Aypay, 2011a; Chan, 2003). This finding seems to support the partnership between sophisticated epistemological beliefs and the constructivist perception of the nature of knowledge and learning. Şengül-Turgut (2007) argue that epistemological beliefs and constructivist perspective of teaching and learning as a theory including the basic assumptions of a dynamic and multi-faceted scientific approach and having some claims about knowledge, reality and external world together create a common context in terms of educational and instructional practices. According to sophisticated epistemological beliefs, knowledge is not simple and unidirectional but made up of complex structures and needs to be questioned; learning, on the other hand, is regarded as a construct coming into being during this process and can be enhanced over time through different experiences (Schommer, 1993).

Another remarkable finding of the study is that there is a positive correlation between the belief that learning depends on effort and both constructivist teaching and learning conception and traditional teaching and learning conception. Similar findings were reported by Aypay (2011a) looking at the pre- 
service teachers' teaching and learning conception and by Kızılgüneş et al. (2009) investigating the learning approaches of sixth grade students. According to constructivist conception, effort is expected for learning to occur, in terms of traditional approach, as students in Turkey always have to prepare for high-stake tests to progress through school, they feel the need to invest effort (Aypay, 2011a). Moreover, teachers might believe that for students to be successful in such a test-centered and competition-based environment they need to work hard.

To sum up, the study has revealed that (i) the epistemological beliefs of the teachers explain a significant part of their teaching and learning conceptions, (ii) the teachers' epistemological beliefs are not sophisticated enough in all dimensions of epistemological construct and (iii) although they favor constructivist teaching and learning conception at a high level, they still have a traditional conception about teaching and learning to a considerable extend. As it is well-known form the literature that teachers' teaching and learning conceptions which are driven by their epistemological beliefs to a considerable extend have significant impacts on teachers' instructional practices. Taking this implication into account, two major recommendations can be made in order to reach high quality instructional practices at schools: (i) In design and development of pre-service teacher education programs and their applications, the purpose of acquiring sophisticated epistemological beliefs to the prospective teachers should be considered as a central factor to effect teaching and learning conceptions of the future teachers in favor of constructivist conception and (i) while present teachers' epistemological beliefs and conceptions about teaching and learning should be improved through the continuous in-service education activities, teaching and learning environments should also be improved in such ways that encourage and allow the reflections of the constructivist conception into practice. Additionally, reasons behind lower sophistication in two dimensions (innate/fixed ability and certainty of knowledge) of epistemological beliefs of the teachers and existence of considerable level of traditional conception in the teachers about teaching and learning in spite of their high level of constructivist conception about teaching and learning should be researched with studies designed in qualitative methodology.

\section{REFERENCES}

Akça, S. (2007). Ilköğretim 5. sınıf matematik programının öğretmen yönetici ve ilköğretim müfettişleri görüşleri doğrultusunda değerlendirilmesi (Afyonkarahisar ili örneği). [Evaluation of the 5 th primary school 2005 mathematics curriculum considering the opinion of teachers, headmasters and inspectors]. Master's thesis, Afyon Kocatepe University, Afyon, Turkey.

Akkaya, Recai. (2010). Olasılık ve Istatistik Öğrenme Alanındaki Kavramların Gerçekçi Matematik Eğitimi ve Yapılandırmacılık Kuramına Göre Bilgi Oluşturma Sürecinin Incelenmesi. [The investigation of knowledge construction process of concepts in probability and statistical learning field according to the realistic mathematic education and constructivism theory]. Doctoral dissertation, Uludağ University, Bursa, Turkey.

Aksan, N., \& Sözer, M. A. (2007). Üniversite öğrencilerinin epistemolojik inançları ile problem çözme becerileri arasındaki ilişkiler. Ahi Evran Üniversitesi Kırşehir Eğitim Fakültesi Dergisi (KEFAD), 8(1), 3150.

Akyıldız, S. 2014. Lise öğretmenlerinin epistemolojik inançları ile öğretme-öğrenme anlayışları arasındaki ilişkinin incelenmesi. [Investigating the relationship between high school teachers' epistemological beliefs and their teaching-learning approaches]. Doctoral dissertation, Fırat University, Elazığ, Turkey.

Aydın, Ö., Tunca, N., \& Alkın-Şahin, S. (2015). Fen bilgisi öğretmen adaylarının öğretme ve öğrenme anlayışlarının çeşitli değişkenler açısından incelenmesi. Kastamonu Eğitim Dergisi, 23(3), 1331-1346.

Aypay, A. (2011a). Öğretme ve öğrenme anlayışları ölçeği'nin Türkiye uyarlaması ve epistemolojik inançlar ile öğretme ve öğrenme anlayışları arasındaki ilişkiler. Kuram ve Uygulamada Eğitim Bilimleri, 11(1), 7-29.

Aypay, A. (2011b). Epistemolojik inançlar ölçeğinin Türkiye uyarlaması ve öğretmen adaylarının epistemolojik inançlarının incelenmesi. Eskişehir Osmangazi Üniversitesi Sosyal Bilimler Dergisi, 12(1), $1-15$.

Anagün, S. S., Yalçinoğlu, P., \& Ersoy, A. (2012). Sınıf Öğretmenlerinin fen ve teknoloji dersi öğretmeöğrenme sürecine ilişkin inançlarının yapılandırmacılık açısından incelenmesi. Journal of Theoretical Educational Science/Kuramsal Eğitimbilim Dergisi, 5(1), 1-16. 
Bacanlı-Kurt, C. (2010). Öğretmenlerin epistemolojik inançları ve değişime direnme tutumları arasındaki ilişkinin incelenmesi. [Examination of relationships between teachers epistemogical beliefs and attitude of resist to organizational change]. Master's thesis, Gazi University, Ankara, Turkey.

Baş, G. (2015). Öğretmenlerin eğitim felsefesi inançları ile öğretme-öğrenme anlayışları arasındaki ilişki. Eğitim ve Bilim, 40(182), 111-126.

Başbay, M. (2013). Epistemolojik inancın eleştirel düşünme ve üstbiliş ile ilişkisinin yapısal eşitlik modeli ile incelenmesi. Eğitim ve Bilim, 38(169), 249-262.

Benson, G. D. (1989). Epistemology and science curriculum. Journal of Curriculum Studies, 21(4), 329-344.

Brownlee, J. M., Thorpe, K. J., \& Stacey, P. S. (2005). Improving learning and teaching in early childhood teacher education: $A$ focus on personal epistemology. Retrieved from http://eprints.qut.edu.au/2126/1/2126.pdf. 22.07.2016.

Büyüköztürk, Ş. (2014). Sosyal Bilimler Iç̧in Veri Analizi El Kitabi. Ankara: PegemA Yayıncılık.

Cano, F. (2005). Epistemological beliefs and approaches to learning: Their change through secondary school and their influence on academic performance. British Journal of Educational Psychology, 75(2), 203-221.

Cano, F.,\& Rodriguez, L. (2006). The epistemological beliefs, learning approaches and study orchestrations of university students. Studies in Higher Education, 31(5), 617-636.

Chan, K-W. (2003). Hong Kong teacher education students' epistemological beliefs to approaches to learning. Research in Education, 69(1), 36-50.

Chan, K-W., \& Elliott, R. G. (2000). Exploratory study of epistemological beliefs to hong kong teacher education students: Resolving conceptual and empirical Issues. Asia Pacific Journal of Teacher Education, 28(3), 225-234.

Chan, K. W., \& Elliott, R. G. (2002). Exploratory study of Hong Kong teacher education students' epistemological beliefs: cultural perspectives and implications on beliefs research. Contemporary Educational Psychology, 27(3), 392-414.

Chan, K. W., \& Elliott, R. G. (2004). Relational analysis of personal epistemology and conceptions about teaching and learning. Teaching and Teacher Education, 20(8), 817-831.

Cheng, M. M., Chan, K. W., Tang, S. Y., \& Cheng, A. Y. (2009). Pre-service teacher education students' epistemological beliefs and their conceptions of teaching. Teaching and Teacher Education, 25(2), 319-327.

Çetin, O., \& Günay, Y. (2007). Fen öğretiminde yapılandırmacılık kuramının öğrencilerin başarılarına ve bilgiyi yapılandırmalarına olan etkisi. Eğitim ve Bilim. 32(146), 24-38.

Çiftçi, S., Sünbül, A. M., \& Köksal, O. (2013). Sınıf öğretmenlerinin yapılandırmacı yaklaşıma göre düzenlenmiş mevcut programa ilişkin yaklaşımlarının ve uygulamalarının değerlendirilmesi. Mersin Üniversitesi Eğitim Fakültesi Dergisi, 9(1), 281-295.

Çokluk, Ö. (2010). Logistic regression: concept and application. Educational Sciences: Theory \& Practice, 10(3), 1357-1407.

Demir, Ö., \& Acar, M. (1992). Sosyal Bilimler Sözlügü. Vadi Yayınları, Ankara.

Demir, S., \& Akınoğlu, O. (2010). Epistemolojik inanışlar ve öğretme öğrenme süreçleri. M.Ü. Atatürk Eğitim Fakültesi Eğitim Bilimleri Dergisi, 32, 75-9.

Demirel, Ö. (2007). Öğretme Sanatı. Ankara: PegemA Yayıncılık.

Deryakulu, D. (2002). Denetim odağı ve epistemolojik inançların öğretim materyalini kavramayı denetleme türü ve düzeyi ile ilişkisi. Hacettepe Üniversitesi Eğitim Fakültesi Dergisi, 22(22), 55-61.

Deryakulu, D. (2014). Epistemolojik inançlar. Y. Kuzgun \& D. Deryakulu (Ed.), Eğitimde Bireysel Farklılıklar, 259-288. Ankara: Nobel Yayınevi.

Ekici, M., \& Kaya, E. (2016). Sosyal bilgiler öğretmenlerinin epistemolojik inançlarıyla öğretim stilleri arasındaki ilişki. Route Educational and Social Science Journal, 3(1), 195-218.

Ekinci, N. (2016). Sınıf öğretmenlerinin öğretme-öğrenme anlayışları ve öğrenen özerkliğini destekleyici davranışları arasındaki ilişkiler. Akdeniz Eğitim Araştırmaları Dergisi, 19, 1-16.

Engin, G. \& Daşdemir, İ. (2015). Sınıf öğretmenlerinin öğretme ve öğrenme anlayışlarının çeşitli değişkenler açısından incelenmesi. International Journal of Social Science, 33, 425-432.

Gallagher, J. J. (1991). Prospective and practicing secondary school science teachers' knowledge and beliefs about the philosophy of science. Science Education, 75(1), 121-133.

Gray, A. (1997). Contructivist teaching and learning. SSTA Research Centre Report, 97-07. Retrieved from http://archive.li/W1TyV. 18.08.2016.

Hashweh, M. Z. (1996). Effects of science teachers' epistemological beliefs in teaching. Journal of Research in Science Teaching, 33(1), 47-63. 
Hofer, B. K. (2001). Personal epistemology research: Implications for learning and teaching. Educational Psychology Review, 13(4), 353-383.

Howard, B. C., McGee, S., Schwartz, N., \& Purcell, S. (2000). The experience of constructivism: Transforming teacher epistemology. Journal of Research on Computing in Education, 32(4), 455-465.

Isikoglu, N., Basturk, R., \& Karaca, F. (2009). Assessing in-service teachers' instructional beliefs about student-centered education: A Turkish perspective. Teaching and Teacher Education, 25(2), 350-356.

İçen, M. (2012). Sosyal bilgiler öğretmenlerinin epistemolojik inançlarının sınıf içi uyguladıkları öğretim stratejileri ile ilişkisi. [The epistemologic beliefs of social science teachers and the teaching strategies they apply in the class]. Master's thesis, Erzincan University, Erzincan, Turkey.

Kagan, D. M. (1992). Implication of research on teacher belief. Educational Psychologist, 27(1), 65-90.

Kalaycı, N. (2014). Yapılandırmacı yaklaşımın sınıf yönetimi ve öğrenme sürecine yansıması. [The constructivist approach to self-regulation and learning in the classroom]. Master's thesis, Sabahattin Zaim University, İstanbul, Turkey.

Kaleci, F. (2012). Matematik öğretmen adaylarının epistemolojik inançları ile öğrenme ve öğretim stilleri arasındaki ilişki. [The relationship between pre?service mathematics teacher?s epistemological beliefs and their learning and teaching styles]. Master's thesis, Necmettin Erbakan University, Konya, Turkey.

Kaleci, F. \& Yazıcı, E. (2012). Epistemolojik inançlar üzerine bir derleme. 10. Ulusal Fen Bilimleri ve Matematik Eğitimi Kongresi. Niğde Üniversitesi. Retrieved from http://kongre.nigde.edu.tr/xufbmek/dosyalar/tam_metin/pdf/2463-30_05_2012-21_30_43.pdf. 25.10.2016.

Karasar, N. (1986). Bilimsel Araştırma Yöntemi: Kavramlar, Illkeler, Teknikler. Nobel Yayın Dağıtım.

Karataş, H. (2011). Üniversite öğrencilerinin epistemolojik inançları, ögrenme yaklaşımları ve problem çözme becerilerinin akademik motivasyonu yordama gücü. [The prediction of academic motivation using university students' epistemological beliefs, learning approaches and problem solving skills]. Doctoral dissertation, Yıldız Teknik University, İstanbul, Turkey.

Kardash, C. M. \& Howell, K. L. (2000). Effects of epistemological beliefs and topic-specific beliefs on undergraduates' cognitive and strategic processing of dual-positional text. Journal of Educational Psychology, 9(3), 524-535.

Karhan, ì. (2007). Illköğretim okullarında görev yapan öğretmenlerin epistemolojik inançlarının demografik özelliklerine ve bilgi teknolojilerini kullanma durumlarına göre incelenmesi. [The investigation of epistemological beliefs of primary school teachers according to some demographic variables and their information technology use]. Doctoral dissertation, Yıldız Teknik University, İstanbul, Turkey.

Kaya, Z. \& Tüfekçi, S. (2008). Yapılandırmacı yaklaşımın erişiye etkisi. Gazi Üniversitesi Endüstriyel Sanatlar Eğitim Fakültesi Dergisi, 23, 79-90

Kızılgüneş, B., Tekkaya, C., \& Sungur, S. (2009). Modeling the relations among students' epistemological beliefs, motivation, learning approach, and achievement. The Journal of Educational Research, 102(4), 243-256.

Köse, S., \& Dinç, S. (2012). Fen ve teknoloji öğretmen adaylarının biyoloji özyeterlik algıları ile epistemolojik inançları arasındaki ilişki. Mustafa Kemal Üniversitesi Sosyal Bilimler Enstitüsü Dergisi, 9(18), 121-141.

Myers, R. (1990). Classical and Modern Regression with Applications. Boston, MA: Duxbury.

Oğuz, A. (2008). Investigation of Turkish trainee teachers' epistemological beliefs. Social Behavior and Personality: An International Journal, 36(5), 709-720.

Oğuz, A. (2011). Öğretmen adaylarının demokratik değerleri ile öğretme ve öğrenme anlayışları. Değerler Eğitimi Dergisi, 9(22), 139-160.

Önen, F. (2005). ilköğretimde basınç konusunda öğrencilerin sahip olduğu kavram yanılgılarının yapılandırmacı yaklaşım ile giderilmesi. [The removing of students misconceptions about pressure with constructivist approach in elementary school]. Master's thesis, Marmara University, İstanbul, Turkey.

Özbaş, N. (2013). Sını öğretmenlerinin düşünme stillerinin kullandıkları yöntemler ve epistemolojik inançları açısından incelenmesi. [Investigation of class teachers' thinking styles through the methods they used and epistemological beliefs]. Master's thesis, Amasya University, Amasya, Turkey.

Özdemir, I., \& Köksal, N. (2014). The evaluation of elementary school teachers' epistemological beliefs. Egitim Bilimleri Fakültesi Dergisi, 47(1), 301-326.

Özdoğan, M. (2008). Yapılandırmacı yaklaşım doğrultusunda hazırlanan yeni sosyal bilgiler programında aktif ögrenme tekniklerinin kullanımı. [The usage of active learning techniques in a new social studies which is prepared in direction of constructivist approach]. Master's thesis, Gaziosman Paşa University, Tokat, Turkey. 
Özkal, K., Tekkaya, C., Cakiroglu, J., \& Sungur, S. (2009). A conceptual model of relationships among constructivist learning environment perceptions, epistemological beliefs, and learning approaches. Learning and Individual Differences, 19(1), 71-79.

Özenç, M., \& Doğan, C. (2007). Sınıf öğretmenlerinin yapılandırmacı yaklaşım yeterlik düzeylerinin belirlenmesi. Abant Izzet Baysal Üniversitesi Eğitim Fakültesi Dergisi, 12(1), 67-83.

Pajares, M. F. (1992). Teachers' beliefs and educational research: Cleaning up a messy construct. Review of Educational Research, 62(3), 307-332.

Richardson, V. (1996). The role of attitudes and beliefs in learning to teach. Handbook of research on teacher education, 2, 102-119. Retrieved from https://www.researchgate.net/profile/Virginia_Richardson2/publication/239666513_The_role_of_attit udes_and_beliefs_in_learning_to_teach/links/572cdb6f08aeb1c73d11b2e2.pdf. 08.10.2016.

Saygın, Ö., Atılboz, N.G., \& Salman, S. (2006). Yapılandırmacı öğretim yaklaşımının biyoloji dersi konularını öğrenme başarısı üzerine etkisi: canlıı̆̆ın temel birimi-hücre. Gazi Eğitim Fakültesi Dergisi, 26(1), 5164.

Schommer, M. (1990). Effects of beliefs about the nature of knowledge on comprehension. Journal of Educational Psychology, 82(3), 498-504.

Schommer, M. (1993). Epistemological development and academic performance among secondary students. Journal of Educational Psychology, 85(3), 406-411.

Schommer, M., \& Walker, K. (1997). Epistemological beliefs and valuing school: considerations for college admission and retention. Research Higher Education, 38(2), 173-186.

Schommer, M., Crouse, A., \& Rhodes, N. (1992). Epistemological beliefs and mathematical text comprehension: Believing it is simple does not make it so. Journal of Educational Psychology, 84(4), 435-443.

Schommer-Aikins, M., \& Hutter, R. (2002). Epistemological beliefs and thinking about everyday controversial issues. The Journal of Psychology, 136(1), 5-20.

Şengül-Turgut, G. (2007). Yapılandırmacı yaklaşıma dayalı öğretimin lise fizik öğrencilerinin epistemolojik inanışlarına etkisi. [The effect of instruction based on constructivist approach on high school physics students' epistemological beliefs]. Master's thesis, Marmara University, İstanbul, Turkey.

Taşkın, Ç. Ş. (2012). Epistemolojik inançlar: Öğretmen adaylarının öğrenme yaklaşımlarını yordayıcı bir değişken. Mustafa Kemal Üniversitesi Sosyal Bilimler Enstitüsü Dergisi, 9(19), 273-285.

Tezci, E., \& Uysal, A. (2004). Eğitim teknolojisinin gelişimine epistemolojik yaklaşımların etkisi. The Turkish Online Journal of Educational Technology (TOJET), 3(2), 158-164.

Woolley, S. L., Benjamin, W. J. J., \& Woolley, A. W. (2004). Construct validity of a self-report measure of teacher beliefs related to constructivist and traditional approaches to teaching and learning. Educational and Psychological Measurement, 64(2), 319-331.

Windschitl, M., \& Andre, T. (1998). Using computer simulations to enhance conceptual change: the roles of constructivist instruction and student epistemological beliefs. Journal of Research in Science Teaching, 35(2), 145-160.

Yanpar-Yelken., Üredi, L., Tanrıseven, I. \& Kılıç, F. (2010). İlköğretim müfettişlerinin yapılandırmacı program ile öğretmenlerin yapılandırmacı öğrenme ortamı oluşturma düzeylerine ilişkin görüşleri. Ç.Ü. Sosyal Bilimler Enstitüsü Dergisi, 19(2), 31-46.

Correspondence

Yrd. Doç. Dr. Necla EKinCi nekinci@mu.edu.tr 